\title{
Medicago truncatula ENOD11: A Novel RPRP-Encoding Early Nodulin Gene Expressed During Mycorrhization in Arbuscule-Containing Cells
}

\author{
Etienne-Pascal Journet, ${ }^{1}$ Naima El-Gachtouli, ${ }^{2}$ Vanessa Vernoud, ${ }^{1}$ Françoise de Billy, ${ }^{1}$ \\ Magalie Pichon, ${ }^{1}$ Annie Dedieu, ${ }^{1}$ Christine Arnould, ${ }^{2}$ Dominique Morandi, ${ }^{2}$ David G. Barker, ${ }^{1}$ \\ and Vivienne Gianinazzi-Pearson ${ }^{2}$ \\ ${ }^{1}$ Laboratoire de Biologie Moléculaire des Relations Plantes-Microorganismes, CNRS-INRA, BP 27, 31326

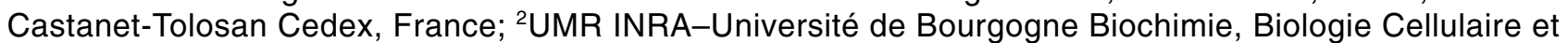 \\ Ecologie des Interactions Plantes-Microorganismes, CMSE-INRA, Dijon, France \\ Submitted 31 October 2000; Accepted 8 February 2001.
}

\begin{abstract}
Leguminous plants establish endosymbiotic associations with both rhizobia (nitrogen fixation) and arbuscular mycorrhizal fungi (phosphate uptake). These associations involve controlled entry of the soil microsymbiont into the root and the coordinated differentiation of the respective partners to generate the appropriate exchange interfaces. As part of a study to evaluate analogies at the molecular level between these two plant-microbe interactions, we focused on genes from Medicago truncatula encoding putative cell wall repetitive proline-rich proteins (RPRPs) expressed during the early stages of root nodulation. Here we report that a novel RPRP-encoding gene, MtENOD11, is transcribed during preinfection and infection stages of nodulation in root and nodule tissues. By means of reverse transcription-polymerase chain reaction and a promoterreporter gene strategy, we demonstrate that this gene is also expressed during root colonization by endomycorrhizal fungi in inner cortical cells containing recently formed arbuscules. In contrast, no activation of MtENOD11 is observed during root colonization by a nonsymbiotic, biotrophic Rhizoctonia fungal species. Analysis of transgenic Medicago spp. plants expressing pMtENOD11-gusA also revealed that this gene is transcribed in a variety of nonsymbiotic specialized cell types in the root, shoot, and developing seed, either sharing high secretion/metabolite exchange activity or subject to regulated modifications in cell shape. The potential role of early nodulins with atypical RPRP structures such as ENOD11 and ENOD12 in symbiotic and nonsymbiotic cellular contexts is discussed.
\end{abstract}

Additional keywords: Glomus spp., in situ hybridization, Sinorhizobium meliloti, transfer cells.

Terrestrial plants have developed the ability to establish mutualistic and reciprocally beneficial symbiotic relationships with soil microorganisms. In such associations, the microsymbionts improve the mineral nutrition of the plant in ex-

Corresponding author: E.-P. Journet; E-mail: journet@toulouse.inra.fr

Current address of N. El-Gachtouli: Département de Biologie, Faculté des Sciences et Techniques de Fès Saiss, Fès, Morocco. change for photosynthates. The most frequent type of root endosymbiosis, the phosphate-acquiring arbuscular mycorrhizal (AM) association, displays little host specificity and involves more than $80 \%$ of extant plant taxa, which interact with a limited number of fungal species belonging to the Glomales order (Smith and Read 1997). When the fungal symbiont contacts the host root surface, it differentiates to form an appressorium and, subsequently, penetrates the root. Penetrating hyphae then grow throughout the cortex and differentiate within inner cortical cells into highly branched structures known as "arbuscules." The arbuscule-cortical cell interface is thought to be the site where phosphate and possibly carbon are transferred between symbionts (Harrison 1999; Smith and Smith 1990). Although the process of colonization has been described clearly, the molecular mechanisms governing recognition between symbiotic partners and the development of the AM symbiosis are still largely unknown.

In contrast to the AM association, which dates back to the Devonian era, the nitrogen-fixing symbiosis with Rhizobiaceae bacteria is more recent on the evolutionary time-scale and restricted almost completely to leguminous plants with a generally narrow host specificity. This well-studied endophytic association leads to the formation of a novel type of plant organ known as the "root nodule," in which bacteria reduce atmospheric nitrogen to ammonia and thus provide the host plant with a privileged source of combined nitrogen. In temperate legumes such as pea and Medicago spp., nodule development is initiated by the specific attachment of rhizobia to young emerging root hairs located close to the root tip, leading to hair curling. Specialized tubular structures known as "infection threads" are then induced in curled root hairs, allowing the invading bacteria to progress toward the inner root cortex, where the initiation of cell division leads to the formation of a nodule primordium. Subsequent growth and coordinated differentiation of both symbiotic partners result in the development of the $\mathrm{N}_{2}$-fixing, indeterminate-type nodule possessing a persistent apical meristem (Hadri et al 1998; Mylona et al 1995).

Molecular mechanisms underlying the Rhizobium-legume symbiotic interaction have been studied in much more detail than for the AM counterpart. The interaction is initiated by a molecular dialog between the two organisms and, in particu- 
lar, the synthesis by rhizobia of specific lipochitooligosaccharide (LCO)-signaling molecules known as "Nod factors," which are of fundamental importance to successful host-bacterial recognition and root nodulation (Albrecht et al. 1999; Schultze and Kondorosi 1998). The whole nodulation process involves the specific expression or up-regulation of a number of plant genes known as "nodulin genes" (Pawlowski 1997). These genes were initially considered to be expressed specifically during symbiotic associations with rhizobia. However, many are now thought to participate in other plant developmental processes because the majority also are expressed in nonsymbiotic plant tissues (Schultze and Kondorosi 1998). A relatively small number of early nodulin genes, postulated to play a role in morphogenetic and organogenetic plant responses, have been characterized. One of the first early nodulin genes to be studied in detail was PsENOD12 (Scheres et al. 1990) encoding a putative cell wall repetitive proline-rich protein (RPRP). We were able to isolate a closely related gene, MtENOD12, from the model legume Medicago truncatula (Pichon et al. 1992), and made use of a promoter-reporter-gene approach to characterize Nod factor-dependent MtENOD12 gene activation in the root epidermis (Journet et al. 1994; Pingret et al. 1998).

Despite clear differences between the two root endosymbioses in terms of host specificity and developmental responses elicited in the host plant, genetic and molecular studies have shown that several common features characterize various stages in the establishment of these symbiotic interactions. The most convincing evidence for this comes from the fact that a significant proportion of legume mutants that have lost the ability to form infection threads and nodules $\left(\mathrm{Nod}^{-}\right)$are also completely resistant to AM fungi $\left(\mathrm{Myc}^{-}\right)$, whereas their interaction with soil pathogens is not affected (Albrecht et al. 1999; Gianinazzi-Pearson 1996; Harrison 1997). Furthermore, a small number of legume nodulin genes have been identified that are transcriptionally activated during both AM and rhizobial interactions, e.g., the early nodulin genes MsENOD2, MsENOD40 (Van Rhijn et al. 1997), PsENOD5, PsENOD12 (Albrecht et al. 1998), and an atypical leghemoglobin gene, VfLb29 (Frühling et al. 1997). In addition, transcripts coding for certain polypeptides that are immunologically crossreactive with nodule-specific plant proteins (nodulins) have been detected in mycorrhizal roots, and monoclonal antibodies raised against components of the infection thread or the peribacteroid membrane in nodules recognize antigenic sites in the periarbuscular interface (Gianinazzi-Pearson 1996). These observations, in conjunction with the much earlier evolution of the AM symbiosis, led to the proposition that some of the plant processes leading to nodulation may have evolved from those preexisting for fungal symbioses (Gianinazzi-Pearson 1997; LaRue and Weeden 1994).

The identification of additional nodulin genes expressed during the establishment of the arbuscular mycorrhizal symbiosis should facilitate comparative studies between both root endosymbioses and, at the same time, provide new molecular markers to better characterize the early stages of AM formation. In this article, we report the characterization of $M t E N O D 11$, an early nodulin gene from the model legume $M$. truncatula encoding a novel RPRP. We show that MtENOD11 is a molecular marker for both early preinfection responses and later infection-related processes occurring within root and symbiotic nodule tissues. Furthermore, we demonstrate that this gene is expressed strongly during the arbuscular mycorrhizal interaction in inner cortical cells containing recently formed arbuscules. We discuss the significance of the similarities and differences between the expression patterns of the two early nodulin genes MtENOD11 and MtENOD12 in symbiotic and nonsymbiotic contexts and, in particular, the possible functions of the corresponding putative cell wall RPRproteins.

\section{RESULTS}

\section{Identification and cloning}

of the single-copy MtENOD11 gene.

In a hybridization experiment performed a number of years ago, several bands of variable intensity were observed when a pea ENOD12 cDNA (Scheres et al. 1990) was used to probe restriction digests of $M$. truncatula genomic DNA under lowstringency conditions (Pichon et al. 1992). The cloning and characterization of the single-copy gene which we named MtENOD12, corresponding to the strongest hybridization signal and clearly homologous at the sequence level with PsENOD12, has been reported (Pichon et al. 1992). Subsequently, we isolated a genomic clone corresponding to one of the weaker cross-hybridizing bands (the $3.0 \mathrm{~kb} E c o \mathrm{RI}$ genomic DNA fragment in Figure 1 in Pichon et al. 1992). This clone contained a gene encoding a second early nodulin, which we named MtENOD11. Southern analysis revealed that the MtENOD11 gene also is single-copy in the M. truncatula genome (data not shown).

\section{Sequence analysis of the MtENOD11 gene and the predicted encoded RPRP.}

The nucleic acid sequence of the MtENOD11 gene, including immediate flanking regions, has been submitted to the EMBL databank as accession no. AJ297721. The 174 amino acid-long sequence deduced from the coding strand of this gene is presented in Figure 1. No alternative open reading frame of significant length could be identified on either strand of the genomic sequence hybridizing to the pea ENOD12 probe, and there is no evidence from sequence analysis that MtENOD11 contains introns. In line with this, reverse transcription-polymerase chain reaction (RT-PCR) amplification of MtENOD11 cDNA generates a fragment of identical size to that predicted from the genomic sequence (see below).

In MtENOD11, the ATG initiation codon is followed by 24 amino acids that, according to the rules of Von Heijne (1983), are likely to serve as a hydrophobic transit signal peptide. This putative N-terminal signal sequence is very similar (60 to $75 \%$ identity) to that found in pea, vetch, alfalfa, and M. truncatula ENOD12 putative precursor proteins (Allison et al. 1993; Pichon et al. 1992; Scheres et al. 1990; Vijn et al. 1995) as well as that of the MsENOD10 nodulin precursor (Löbler and Hirsch 1993). The remaining coding sequence is composed mainly of the repeating pentapeptide element PPXXX, a structural feature characteristic of a family of (hydroxy)proline-rich cell wall proteins known as RPRPs, which were originally characterized in soybean (Hong et al. 1990). The mature MtENOD11 sequence (as is the case for MtENOD12) contains relatively few (5) tyrosines compared with classical RPRPs (Kieliszewski and Lamport 1994) due to the fact that 
this amino acid virtually is absent from the repeating pentapeptide motif. Although MtENOD11 and MtENOD12 possess similar overall structures, MtENOD11 is approximately twice as long as MtENOD12. Furthermore, the two PPXXX repeat regions cannot be aligned, and the sequences flanking the two repeat regions share no homology. Moreover, the repeated pentapeptide motifs are extremely variable in MtENOD11 and cannot be grouped into decapeptide repeats as is the case for MtENOD12 (Pichon et al. 1992).

\section{MtENOD11 transcripts localize to the prefixation zone of the nitrogen-fixing nodule.}

Northern hybridization experiments with a MtENOD11 specific probe had initially shown that this gene is expressed throughout most of nodule development and that the MtENOD11 transcript level is at its highest prior to the onset of $\mathrm{N}_{2}$ fixation (data not shown). This also is the case for MtENOD12 (Pichon et al 1992), although MtENOD11 transcript levels are approximately fivefold higher. The tissuespecific location of MtENOD11 transcripts within the nodule was examined using in situ hybridization. Sections of M. truncatula nodules, harvested either 4 days or 2 to 3 weeks postinoculation, were hybridized with a ${ }^{35} \mathrm{~S}$-labeled antisense RNA probe. Figure 2A shows that MtENOD11 mRNA is present throughout most of the central tissue of the young emerging nodule at 4 days post-inoculation (dpi). Control experiments with sense probes gave low-level, uniform backgrounds (data not shown). At this early stage of development, the nodule is approximately spherical in shape with a central differentiating tissue in which ramifying intercellular infection threads penetrate the plant tissue located below the recently formed nodule meristem. Equivalent experiments carried out on sections of 2- to 3-week-old mature nitrogen-fixing nodules showed that MtENOD11 transcripts are now restricted to a narrow band at the distal end of prefixation zone II, the region of the nodule where bacteria are released from the infection threads (Fig. 2B) (definition of nodule zones in Vasse et al. 1990). A closer examination of this region (Fig. 2C) revealed that transcripts are predominantly present in the submeristematic preinfection zone, i.e., in the two or three cell layers in which infection threads are not yet visible (Pichon et al 1992). The hybridization signal drops to background levels toward the middle of zone II, where bacteroids and plant cells are rapidly codifferentiating. Therefore, MtENOD11 expression is initiated in an identical region of the nodule, as described for MtENOD12 (Pichon et al 1992). MtENOD12 transcripts, however, are still present in more proximal tissues of the prefixation zone, suggesting either a wider transcription window for MtENOD12 or differences in the transcript stability of the two genes.

\section{MtENOD11 also is expressed during early stages of the interaction with Sinorhizobium meliloti.}

To complement in situ hybridization studies and facilitate analysis of MtENOD11 gene expression during both the earlier stages of nodulation and the association with endosymbiotic fungi (see below), we made use of a transgenic M. truncatula line expressing a fusion between the MtENOD11 promoter $(2.3 \mathrm{~kb})$ and $g u s A$ reporter gene. The construction of the transcriptional fusion and the subsequent generation of this representative line (L416) containing a single-copy
pMtENOD11-gusA homozygous transgene, are described elsewhere (D. G. Barker, J. L. Pingret, M. Chabaud, and E.-P. Journet, unpublished).

Following Sinorhizobium meliloti inoculation, activation of the MtENOD11 promoter was first detected after 3 to $6 \mathrm{~h}$ in epidermal tissues lying behind the root tip and corresponding to the region of root hair emergence and development (Fig. 2D). This epidermal response occurs both in the primary and lateral roots, precisely in the region where successful infections will occur 1 to 2 days later (Bhuvaneswari et al. 1981). In line with these results, accumulation of MtENOD11 transcripts as early as $3 \mathrm{~h}$ postinoculation had been previously detected in polyA ${ }^{+}$mRNA extracts (Gamas et al. 1996). Note that GUS staining also is present at the apex of L416 roots (Fig. 2D). This corresponds to nonsymbiotic MtENOD11 gene expression in root cap cells and will be discussed in more detail later. At 3 dpi, developing nodules first become visible as root outgrowths (Fig. 2E) and GUS staining is now present within the central tissue, which agrees with the in situ hybridization results presented earlier for 4-day-old nodules. In addition, intense GUS staining is clearly visible on the root surface at infection sites (Fig. 2E), either above developing nodules or where infections in root hairs have arrested (Penmetsa and Cook 1997; Vernoud et al 1999). At later stages of nodule development, GUS activity becomes restricted to the distal end of the central tissue (Fig. 2F), again in line with the in situ hybridization data (Fig. 2B and C). Thus, our results show that, as for MtENOD12 (Pichon et al. 1992), $M t E N O D 11$ gene expression can be correlated with preinfection and infection events throughout nodulation.

\section{Expression of MtENOD11}

during the arbuscular endomycorrhizal interaction.

Because the AM symbiotic interaction shares common features at the molecular and genetic levels with its rhizobial counterpart (see above), we examined whether the early nodulin gene MtENOD11 also is transcribed during AM formation. As transgenic plants carrying promoter-GUS gene

\section{MASFFLYSLGLVELSALTLVPLGLADKS P}

\section{SHNMPPNPIYT TPIHK NPTNT $\underline{\underline{\underline{\text { PVINP }}}}$}

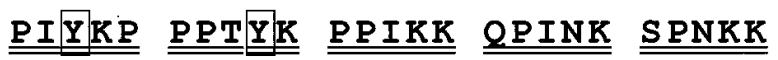

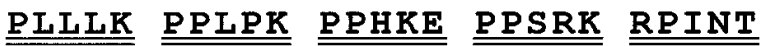

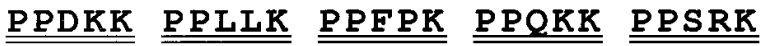

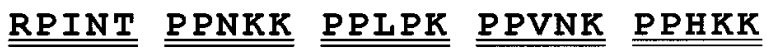

\section{PSNKR PPPYGNQPPPSIHF}

Fig. 1. Predicted amino-acid sequence of the MtENOD11 polypeptide. The putative signal peptide is in italics, and the peptide cleavage site is marked by an arrow. The 24 proline-rich pentapeptide motifs are double underlined, and the five tyrosine residues in the mature polypeptide are boxed. 

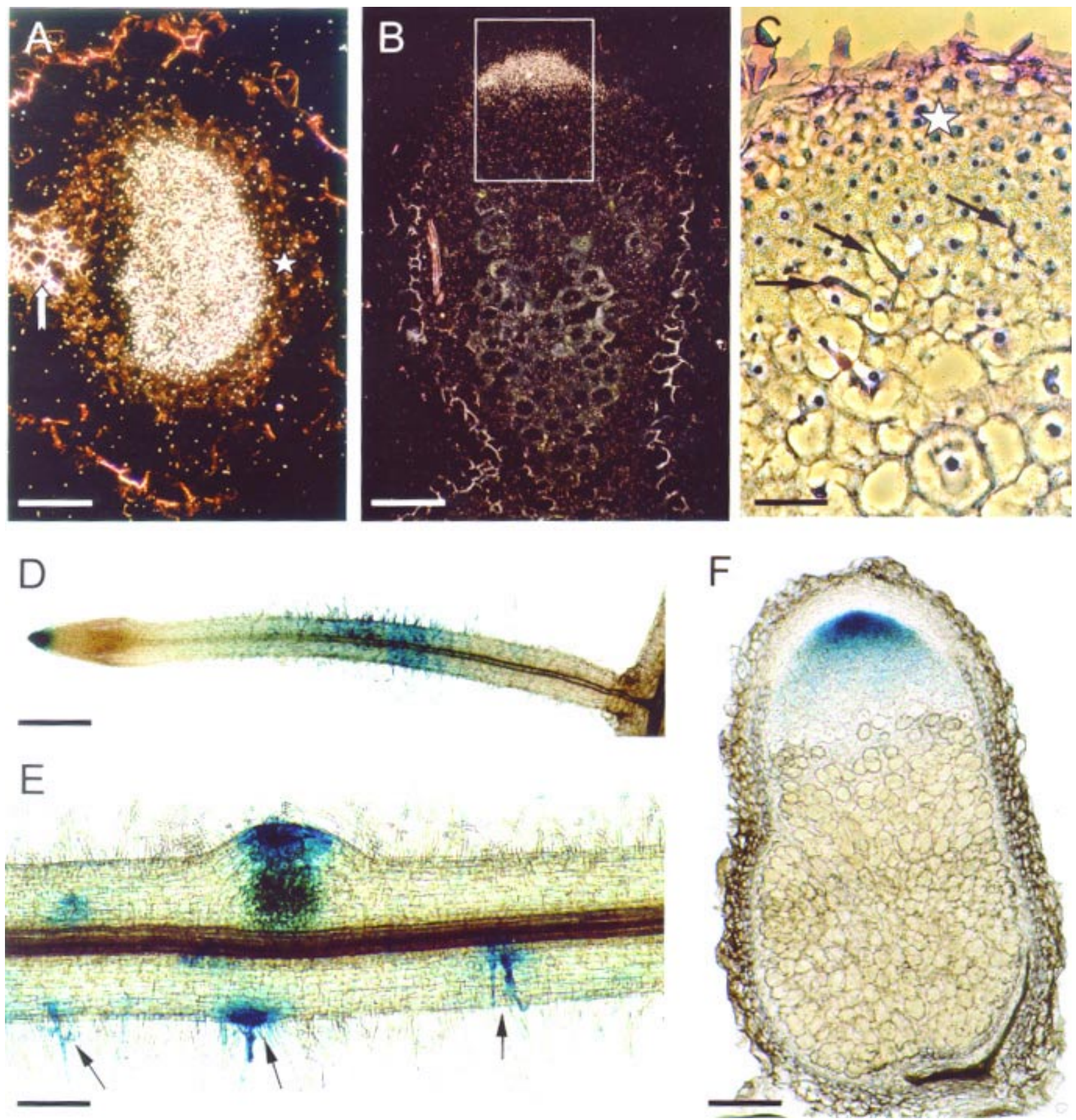

Fig. 2. Analysis of MtENOD11 expression during early and late stages of nodulation. A and B, Dark-field images of MtENOD11 mRNA localization in 7- $\mu \mathrm{m}$ nodule longitudinal sections by in situ hybridization with ${ }^{35}$ S-labeled antisense riboprobes (radioactive labeling appears as bright spots). A, Young nodule harvested 4 days postinoculation showing a uniform pattern of hybridization throughout most of the central tissue. White star indicates the meristematic zone; white arrow indicates the root vasculature. Bar $=80 \mu \mathrm{m}$. B, Mature nodule harvested 3 weeks after inoculation. The hybridization signal is localized at the distal end of prefixation zone II. Bar $=150 \mu \mathrm{m}$. C, Bright-field image of the framed region in B, showing that MtENOD11 transcripts (radioactive labeling now appears as dark spots) are present predominantly in the 2-3 cell layers of the submeristematic preinfection zone where infection threads are not yet visible. White star indicates the nodule meristematic zone, and arrows point to distally located infection threads. Bar $=50 \mu \mathrm{m}$. D-F, Histochemical localization of GUS activity in the transgenic line L416 expressing pMtENOD11-gusA. D, Young lateral root $18 \mathrm{~h}$ postinoculation, showing epidermal MtENOD11 promoter activation in the region of developing root hairs. Note the constitutive GUS staining in root cap cells at the root apex (Fig. 4E). Bar $=900 \mu \mathrm{m}$. E, Lateral root 3 days postinoculation. GUS staining is visible in the outer tissues of an emerging nodule corresponding to the initial infection site and in the deeper tissues corresponding to the invaded nodule primordium. Several sites of arrested infections also are visible on the lower root surface (arrows). Bar $=250 \mu \mathrm{m}$. F, Longitudinal section of a 3-week-old nitrogen-fixing nodule. GUS activity is restricted to the distal end of the central tissue. $\mathrm{Bar}=200 \mu \mathrm{m}$. 
fusions are particularly well suited for analyzing gene expression at the cellular level, we initially made use of the M. truncatula L416 transgenic line described above to evaluate pMtENOD11-gusA expression in root systems colonized by Glomus species. L416 plants were therefore grown in pots and inoculated with Glomus fasciculatum (see below), and roots were harvested at a stage corresponding to approximately 20 to $30 \%$ root colonization. Histological GUS staining revealed strong reporter gene expression in longitudinal stretches located in inner root tissues (Fig. 3A). A closer examination of root segments making use of both transverse root sectioning (Fig. 3B and C) and counterstaining for fungal structures (Fig. 3D) allowed us to determine that the intense GUS staining correlated with the presence of arbuscule-containing cells located in the innermost cortical cell layers. Adjacent cortical cells also showed some GUS activity, although at a significantly lower level (Fig. 3B and C). In contrast, GUS activity in the root inner cortex was totally absent both in control uninoculated transgenic plants and in nontransgenic mycorrhizal roots (data not shown). This latter control allowed us to conclude that the staining in mycorrhizal L416 transgenic roots cannot be attributed to fungal GUS-like enzyme activity, which means that the blue coloration occasionally found within internal hyphae in the vicinity of arbuscule-containing cells in L416 (Fig. 2C) is probably an artifact resulting from the local diffusion of the soluble monomeric GUS-reaction product (Gallagher 1992). MtENOD11 expression in arbuscule-containing cells was systematically observed whether plants were grown in soil or in the axenic in vitro system described later and with all Glomus species tested (see below). Finally, a transgenic alfalfa (Medicago varia) line harboring the pMtENOD11-gusA construct gave very similar results in terms of GUS localization following fungal colonization (data not shown).

Because Northern analysis with total RNA (P. Gamas, personal communication) and in situ hybridization proved insufficiently sensitive to detect MtENOD11 mRNA accumulation in mycorrhizal roots, we used RT-PCR to evaluate endogenous MtENOD11 gene activation during symbiotic fungal colonization. Figure 4 shows that MtENOD11 transcripts could be detected clearly by RT-PCR in RNA extracted from mycorrhizal roots of $M$. truncatula plants grown in smaller pots to speed up colonization (see below) and harvested 2 weeks after inoculation with Glomus mosseae (30\% root colonization). MtENOD11 mRNA, however, was undetectable in control uninoculated roots (Fig. 4). Furthermore, no DNA was amplified when the reverse transcriptase step was omitted, thus showing that the PCR signal is not the result of amplification of contaminating genomic DNA (data not shown). The quality and the relative quantities of the cDNAs used were confirmed by performing parallel amplifications with primers specific for the constitutively expressed MtPR10-1 gene (see below) (Gamas et al. 1998). Comparable results were obtained in three independent experiments with mRNA extracted from mycorrhizal tissues either 2 or 3 weeks after inoculation.

The time course of pMtENOD11-gusA expression over a lengthy mycorrhization period was then determined with plants grown in larger pots (see below). Transgenic $M$. varia seedlings were transplanted to a clay substrate containing a $G$. fasciculatum inoculum and whole root systems were harvested at regular intervals 1 to 10 weeks later. The degree of mycorrhization and the functional activity of internal fungal structures were assessed by quantifying arbuscule abundance in representative root samples (Trouvelot et al. 1986) that were stained for total fungal structures with trypan blue (TB) or for alkaline phosphatase activity (ALP), a vacuolar enzyme marker for active fungal structures (see below) (Smith and Gianinazzi-Pearson 1988). Note that root colonization was slower under these culture conditions than for the RT-PCR experiments described above. Over the 10 -week period, there was a progressive increase in the proportion of the root containing visible arbuscules (TB staining), reaching a final value of $70 \%$ (Fig. 5). On the other hand, and despite some variation, both the proportion of the root system containing functional arbuscules (ALP staining) and the proportion with positive GUS staining reached a plateau value of approximately $10 \%$ after 2 to 4 weeks. Similar results were obtained with $M$. truncatula L416 transgenic plants (data not shown). We presume that this correlation reflects the association of ALP and GUS activities in the same arbuscule-containing cells and is consistent with the fact that GUS-negative, arbusculecontaining cells were generally found in older parts of the root system (data not shown) where arbuscules are mostly inactive or senescent (Tisserant et al. 1996). Our interpretation of these data is that MtENOD11 expression correlates with the functional arbuscule and that transcription is switched off prior to or during arbuscule senescence.

In order to obtain information concerning reporter gene expression during the earlier stages of fungal colonization, experiments were performed making use of an axenic in vitro mycorrhization system developed to facilitate spatiotemporal studies. Germinated seedlings of transgenic $M$. truncatula or $M$. varia expressing pMtENOD11-gusA were transferred to an agar medium containing an actively growing inoculum composed of Glomus intraradices-infected carrot hairy roots (see below) (Bécard and Piché 1992). GUS-positive sites were first detected approximately 5 days after planting, and microscopical analysis revealed that all of these sites contained at least a single arbuscule (not shown). Most sites staining for GUS were located on lateral roots that had formed after planting and therefore corresponded to recent (i.e., $\leq 3$-day-old) colonization events. These observations again show that MtENOD11 gene expression within the root inner cortex during the AM interaction is linked to fungal arbuscule formation and further suggest that the gene is activated during the early stages of arbuscule development.

To determine whether ENOD expression can be triggered by other biotrophic root fungal associations, we challenged $M$. truncatula transgenic plants with a nonpathogenic rootinfecting fungus, a binucleate Rhizoctonia species (see below). The mycelium of this fungus develops on the root surface and forms typical monilioid clusters in epidermal cells but does not penetrate deeper into the root. Whole-root systems were stained for GUS activity and the presence of fungal structures at 2 and 3 weeks postinoculation. Although the extent of root infection by Rhizoctonia reached 15 and 35\%, respectively, pMtENOD11 reporter gene activity could not be detected in the root periphery or cortex (data not shown). This suggests that fungal induction of MtENOD11 is specific to the symbiotic mycorrhizal association. 


\section{Expression of pMtENOD11-gusA}

\section{in nonsymbiotic cellular contexts.}

During our studies of MtENOD11 expression in root tissues related to the establishment of both bacterial and fungal endosymbioses, we also observed reporter gene expression in nonsymbiotic tissues. As mentioned earlier, GUS activity is present in root apices of actively growing roots of L416 (Fig. 2D). Microscopical examination of whole root tips and thin longitudinal sections revealed that pMtENOD11-gus A is, in fact, expressed in the root cap cells (Fig. 3E). Isolated peripheral GUS-staining cells also were found in loose contact with the epidermis behind the root apex. These correspond to the "border cells" (Hawes et al. 1998) that have sloughed off from the root cap. GUS staining was also observed in lateral root primordia (Charlton 1996) in clusters of dividing pericycle cells adjacent to the primary root vasculature and was maximal at early stages of lateral root formation (Fig. 3F). Occasionally, nonlocalized GUS activity was also detected in the pericycle tissue of older root parts.

In aerial organs of L416, relatively strong GUS activity was detected in cotyledon (Fig. 3G) and leaf vascular strands (illustrated for a recently opened leaf in Fig. 3H) and in pulvini, leafmoving organs located at the base of the stalk of each leaflet and leaf (data not shown). Stomatal guard cells (except on young stalks before leaf expansion and leaf blades) also stain for GUS activity (Fig. 3I). Reporter gene expression was observed for glandular trichomes, although in this case staining was most intense on young stalks, where stomata do not stain (Fig. 3J). The precise relationship between $M t E N O D 11$ gene expression and the developmental stage of the plant tissue for these two specialized epidermal cell types remains to be determined.

During seed development, the pMtENOD11-gusA reporter was strongly expressed in i) the embryo suspensor as early as 5 to 7 days after pollination (Fig. $3 \mathrm{~K}$ ); ii) the epidermis and underlying tissue of the cotyledons, hypocotyl, and radicle in maturing embryos (approximately 18 days after pollination onward (Fig. 3L); and iii) the outer cell layer of the endosperm (approximately 10 days after pollination onward) (Fig. 3M), which appears as a thin envelope enclosing the embryo. This cell layer displays a characteristic cell morphology that may be related to transfer cell function (Fig. 3N). The identity of this tissue was established by crossing wild-type $M$. truncatula plants with the transgenic L416 line. In the resulting developing hybrid $F_{1}$ seeds, GUS activity was always in the embryo and the surrounding endosperm, both of which derive from the same doublefertilization event. The GUS-staining pattern described for the L416 line in nonsymbiotic tissues was also observed in all other independent transgenic $M$. truncatula lines analyzed and was unaltered in the presence of rhizobial or fungal symbionts. Similar patterns were observed in the case of $M$. varia lines, except for expression in trichomes. In the control wild-type Medicago spp. plants, no evidence was found for endogenous GUS-like activity in any organ, except for a low-level background blue coloration in the developing seed endosperm, mature pollen, and secondary vascular tissue.

\section{DISCUSSION}

\section{MtENOD11, a new molecular marker for early stages of root nodulation.}

In this paper we report the identification of a novel early nodulin gene from $M$. truncatula, MtENOD11, and the charac- terization of its expression with complementary approaches involving both in situ hybridization and the histochemical localization of reporter gene activity (GUS) driven by the MtENOD11 promoter in transgenic Medicago spp. plants. Within hours of inoculation by S. meliloti, the pMtENOD11gusA fusion is activated in differentiating epidermal tissues located close to the root tip, corresponding to the region of root hair emergence and development. In legumes such as Medicago spp., these types of emerging root hairs are the main targets for $S$. meliloti attachment and penetration leading to successful infection and nodulation (Bhuvaneswari et al 1981; Caetano-Anollès and Gresshoff 1991). Parallel experiments revealed that transcription of pMtENOD11-gusA can also be triggered in differentiating epidermal cells following the addition of subnanomolar concentrations of purified Nod factors of S. meliloti (D. G. Barker, J. L. Pingret, M. Chabaud, and E.-P. Journet, unpublished). At later stages of nodulation, MtENOD11 promoter activity in both root and nodule tissues correlates with the presence of infection threads. This gene is therefore a molecular marker in Medicago spp. for both preinfection and infection events in root and nodule cells throughout the rhizobial symbiotic interaction and, in this respect, closely resembles the MtENOD12 gene, also encoding a RPRP (Pichon et al. 1992). The significantly higher steadystate transcript levels of MtENOD11 (approximately fivefold), also reflected in the respective transgenic lines, make this a superior molecular marker in terms of sensitivity. Interestingly, there are differences between MtENOD11 and $M t E N O D 12$ gene expression patterns and those reported for ENOD12 genes in other legumes. For example, PsENOD12A (Scheres et al. 1990), VsENOD12 (Vijn et al. 1995), and MsENOD12A (Bauer et al. 1996) are all expressed in nodule primordia prior to bacterial invasion, whereas this is not the case for either MtENOD12 (Pichon et al. 1994) or MtENOD11 (not shown). Finally, whilst genomic hybridization studies indicate that ENOD11 probably also exists in the closely related alfalfa (not shown), we do not yet know if an ENOD11 ortholog exists in other legumes.

\section{MtENOD11 is expressed in root inner cortical cells during endomycorrhizal arbuscule development.}

When transgenic Medicago spp. roots are inoculated with Glomus spp. of AM fungi, the pMtENOD11-gusA fusion is activated strongly and specifically in inner cortical cells containing arbuscules. We confirmed by RT-PCR that the endogenous MtENOD11 gene is, indeed, activated transcriptionally during AM colonization. The rapidity of pMtENOD11gusA transcriptional activation during mycorrhizal colonization of $M$. truncatula seedlings, together with results from time-course studies with mature plants, are consistent with the induction of the MtENOD11 promoter during arbuscule development. Because MtENOD11-gusA expression is probably switched off prior to or during arbuscule senescence (Fig. 5) and arbuscules are ephemeral fungal structures that start to senesce several days after reaching full development (Alexander et al. 1989), this reporter gene provides a useful molecular marker to follow the asynchronous formation of AM infection units in whole root systems and, in particular, the longitudinal progression of root colonization in the inner cortex. Preliminary observations suggest that, during such longitudinal colonization of the root by internal hyphae, pMtENOD11- 
gusA expression precedes visible arbuscular differentiation in inner cortical cells. This suggests that the gene may be switched on very early during arbuscule development. Experiments with transgenic Medicago spp. lines expressing a pMtENOD12-gusA fusion (Chabaud et al. 1996; Pichon et al. 1992) revealed that the $M t E N O D 12$ promoter is also activated in mycorrhizae with the same cell specificity as for MtENOD11 (not shown). MtENOD12 expression levels, however, appear to be significantly lower than for MtENOD11, reflecting the quantitative difference already observed during root nodulation.

In a recent study, Albrecht et al. (1998) examined the expression of the two early nodulin genes PSENOD5 and PsENOD12A during the interaction of pea roots with the AM fungus Gigaspora margarita. It was shown by RT-PCR that PsENOD12A transcripts accumulate at an early stage of the endomycorrhizal interaction and that steady-state levels decrease as colonization proceeds and the first arbuscules develop. This pattern of expression is clearly different from that observed for MtENOD11 and MtENOD12. However, we are currently developing an in vitro-targeted inoculation system to investigate whether the two MtENOD genes might also be switched on transiently during the earliest stages of mycorrhizal colonization. Other nodulin genes are also expressed during the AM symbiosis, including a Vicia faba leghemoglobin gene (Frühling et al. 1997) and alfalfa ENOD2 and ENOD4O genes (Van Rhijn et al. 1997). In situ hybridization analyses have shown that MsENOD40 is expressed in the root pericycle and inner cortical cells containing immature arbuscules, whereas MsENOD2 transcripts are located in cortical cells containing mature arbuscules (Van Rhijn et al. 1997). Taken together, these results show that several types of nodulin genes are also activated transcriptionally during AM symbiosis. It is important to underline, however, that little is known so far about the extent to which the regulatory pathways leading to the activation of these various genes are common to both nodulation and endomycorrhization.

\section{Possible roles for the ENOD11 \\ and ENOD12 repetitive proline-rich proteins.}

The nucleotide sequences of the MtENOD11 and MtENOD12 genes predict that they both encode RPRPs (Kieliszewski and Lamport 1994; Showalter 1993). However, the respective PPXXX repeat regions cannot be aligned, and the sequences flanking the repeat regions share no homology, making it unlikely that they have evolved from a common ancestral gene. The presence of an $\mathrm{N}$-terminal signal peptide that is well conserved among members of the legume PRP family, e.g., MtPRP1 and MtPRP2 (Wilson et al. 1994), PsENOD12 (Scheres et al. 1990), and SbPRP3 (Hong et al. 1990), implies that both polypeptides follow a common secretory pathway and are probably targeted to the extracellular matrix by analogy with the known cellular location of SbPRPs (Ye et al. 1991) and pea RPRPs (Sherrier and VandenBosch 1994).

One striking feature of ENOD11 and ENOD12 proteins is their low overall tyrosine (Tyr) content and the virtual absence of this particular amino acid within the repeated pentapeptide motif. This contrasts with the situation for classical RPRPs, where Tyr is frequently part of the repeat motif (Kieliszewski and Lamport 1994). It has been proposed that Tyr residues in proline-rich structural proteins can be involved in intramolecular and intermolecular cross linking, and that this could be responsible for the observed insolubilization of HRGPs and PRPs in cell walls during developmental or defense responses. Such posttranslational cross-linking is presumed to result in the mechanical strengthening of the cell wall and the consequent fixation of cell shape. Cross-linking also might contribute to the restriction of wall porosity that appears to be determined primarily by the pectin matrix (Carpita and Gibeaut 1993, Showalter 1993). If this is the case, then the presence in the cell wall of significant quantities of ENOD11 and ENOD12-type proteins with a low potential for the formation of Tyr-dependent intermolecular cross-links might result in a reduced capacity for wall strengthening and a higher matrix porosity.

During the interaction of roots with Rhizobium spp., symbiotic MtENOD11 and MtENOD12 expression is linked to (pre)infection events in epidermal, cortical, and nodule cells. Thus, both gene products may be involved either in the modification of the root hair cell wall for subsequent penetration of bacteria or in the synthesis of new components required for the infection thread matrix, as proposed previously for PsENOD12 (Scheres et al. 1990). It is probable that lower levels of cross-linking and greater plasticity are important requirements for such walls. Our transgenic plant studies have revealed that MtENOD11 also is expressed in root cap cells, cotyledon and leaf vascular strands, leaf pulvini, stomatal guard cells, glandular trichomes, the suspensor and outer tissues of the developing embryo, and the seed endosperm (Fig. 3). All of these specialized cell-types and/or tissues share the capacity for high secretion/metabolite exchange, i.e., root cap and border cells (Hawes et al. 1998; Rougier 1981), phloem and associated cells in leaves (Esau 1977), glandular trichomes (Wagner 1991), endosperm (Lopes and Larkins 1993), embryo suspensor (Yeung and Meinke 1993), the outer epidermis of embryonic cotyledons (Weber et al. 1998), and/or regulated and reversible variations of cell shape/volume, i.e., pulvinus (Coté 1995) and stomatal guard cells (Assmann 1993), for which high cell wall porosity or plasticity are probably essential characteristics.

In the case of MtENOD12 and in contrast with MtENOD11, nonsymbiotic expression has been detected only in differentiating xylem cells of lateral root primordia, outer tissues of developing embryos, and the surrounding endosperm (Journet et al. 1994; data not shown). Whereas the nonsymbiotic expression patterns of the two early nodulin genes are therefore significantly different, it is striking that their transcriptional regulation is very similar in symbiotic contexts. It is thus possible that MtENOD11 and MtENOD12 were recruited for symbiotic functions through the acquisition of additional promoter elements to ensure coordinated expression. It has been reported that the absence of a functional ENOD12 allele in particular genotypes of diploid alfalfa does not affect their capacity to establish an efficient $\mathrm{N}_{2}$-fixing symbiosis with $S$. meliloti (Csanadi et al. 1994). Bearing in mind the similarities between the symbiotic expression patterns of MtENODI1 and $M t E N O D 12$, this finding could be explained most simply by functional redundancy between the two RPRPs.

Finally, MtENOD11 and MtENOD12 are also expressed during the endomycorrhizal symbiosis with AM fungi in root cortical cells containing recently formed arbuscules. Several 
plant genes and proteins are expressed in cortical cells where arbuscules develop, including cell wall proteins that are presumed to be involved in the major extracellular matrix modifications characteristic of this highly differentiated structure (Bonfante 2001). Arbuscules result from intracellular penetration by the microsymbiont and correspond to the mature functional structure assumed to be involved in metabolite ex- change between the two symbiotic partners (GianinazziPearson 1996; Harrison 1999). The expression of MtENOD11 and $M t E N O D 12$ in these cells might therefore be related either to hyphal infection, leading to modifications in the properties of the existing cell wall, or to elaboration of the new arbuscular matrix interface. To help answer these questions, studies are now under way to determine the precise cellular location
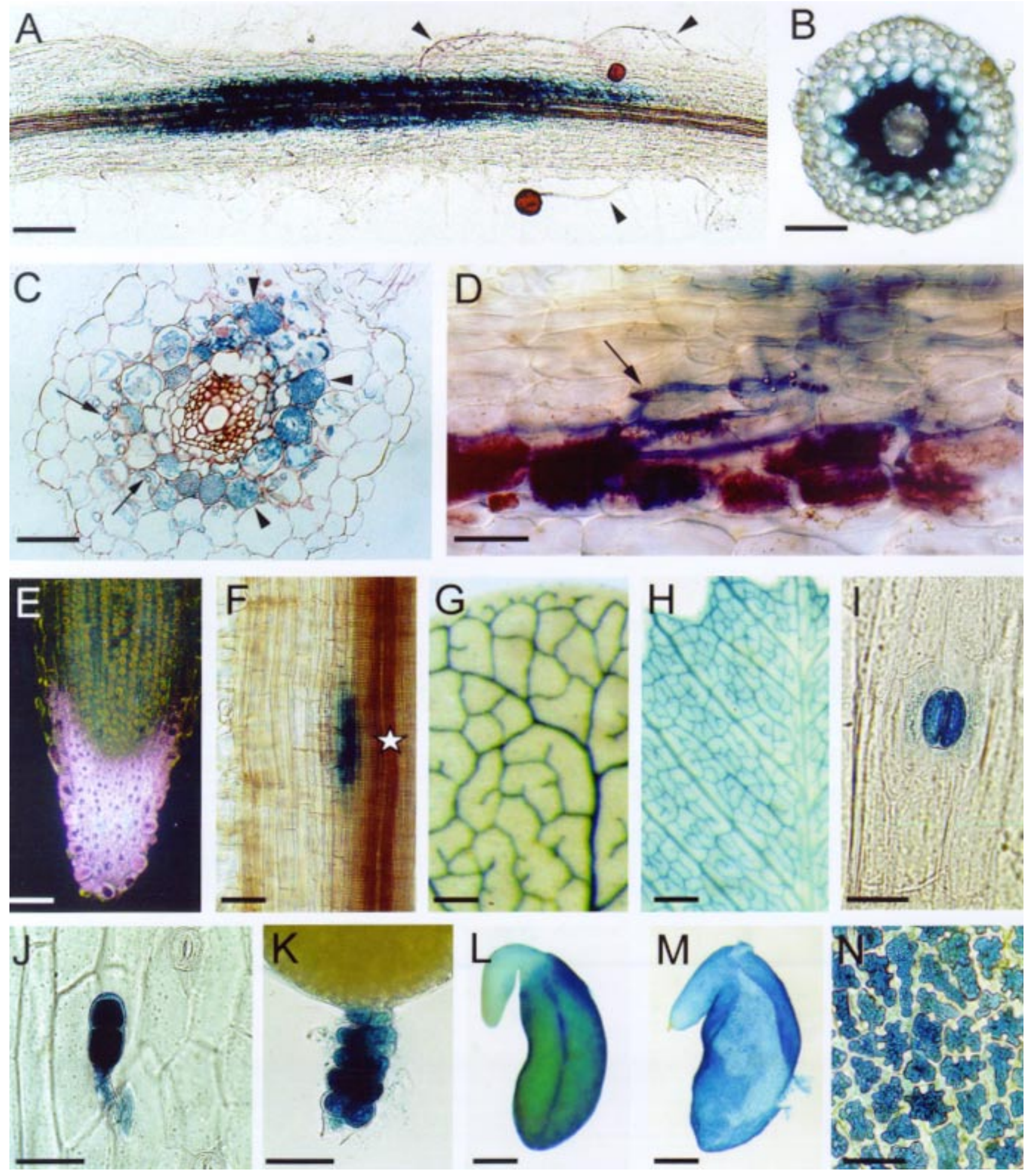
of MtENOD11 and MtENOD12 proteins during symbiotic interactions and nonsymbiotic developmental processes.

\section{MATERIALS AND METHODS}

\section{Isolation of the MtENOD11 genomic clone.}

The construction of the genomic library of $M$. truncatula leaf DNA in a phasmid vector and the screening of this library with a pea ENOD12 cDNA probe (Scheres et al 1990) have been described (Gallusci et al 1991; Pichon et al. 1992). The clone containing MtENOD11 had a total insert size of approximately $13.5 \mathrm{~kb}$, and the MtENOD11 coding sequence was localized within the insert by hybridization. The nucleotide sequence of MtENODI1 has been submitted to the EMBL databank as accession no. AJ297721.

\section{Plant material and microbial strains.}

The wild-type $M$. truncatula Gaertn. cv. Jemalong lines used in this study are either A17 or J5 (provided by T. Huguet, Toulouse, France, and G. Duc, Dijon, France, respectively). The construction of the pMtENOD11-gusA transcriptional fusion and the subsequent generation of the $M$. truncatula line L416 containing a single-copy homozygous transgene are reported elsewhere (D. G. Barker, J. L. Pingret, M. Chabaud, and E.-P. Journet, unpublished). The M. varia lines expressing pMtENOD11-gusA were obtained using the transformation protocol described in Pichon et al. (1992). The M. varia and $M$. truncatula transgenic lines expressing the pMtENOD12gusA construct are described in Pichon et al. (1992) and Chabaud et al. (1996), respectively.

The wild-type $S$. meliloti strain RCR2011 was grown at $28^{\circ} \mathrm{C}$ in standard liquid TY medium supplemented with $6 \mathrm{mM}$ $\mathrm{CaCl}_{2}$. G. mosseae (Nicol. \& Gerd.) Gerd. and Trappe (isolate BEG12) and G. fasciculatum (Thaxter sensu Gerd.) Gerd. \& Trappe (isolate BEG 53) were cultured on roots of the host plant Allium porrum L. in soil-based gnobiotic pot cultures in a growth cabinet $\left(200 \mu \mathrm{E} \mathrm{cm} \mathrm{cm}^{-2} \mathrm{~s}^{-1}, 25^{\circ} \mathrm{C}, 16-\mathrm{h}\right.$ photoperiod, $70 \%$ relative humidity). A G. intraradices inoculum, provided by G. Bécard (Université P. Sabatier, Toulouse, France), was propagated by axenic co-culture of the AM fungus with Daucus carota hairy roots on solid medium according to Bécard and Piché (1992). The nonpathogenic binucleate Rhizoctonia species used in this study was isolated from a soil sample of the INRA Experimental Domaine (Dijon, France) and characterized as belonging to the anastomosis group AG A. This
Rhizoctonia species was cultivated in vitro according to Camporota (1989) to produce an inoculum that was incorporated in the plant growth substrate at $1 \mathrm{~g}$ of mycelium per liter.

\section{Plant growth and inoculation conditions.}

For nodulation experiments, germinated $M$. truncatula or $M$. varia seedlings were grown in aeroponic conditions at $22^{\circ} \mathrm{C}$ with a relative humidity of $75 \%$, a 16 -h photoperiod, and light intensity (photosynthetically active radiation) of $200 \mu \mathrm{E}$ $\mathrm{m}^{-2} \mathrm{~s}^{-1}$. After 2 to 3 weeks growth on medium containing $5 \mathrm{mM} \mathrm{NH} \mathrm{NO}_{3}$ (Gallusci et al. 1991), combined nitrogen was removed from the medium and plants were inoculated 3 days later with the wild-type $S$. meliloti strain $\left(5 \times 10^{5}\right.$ bacteria per $\mathrm{ml})$.

For mycorrhization experiments with transgenic lines, seedlings were transplanted into large pots $(400 \mathrm{ml})$ containing $2 / 3$ vol of a calcined clay substrate (Terragreen) mixed with $1 / 3$ volume of a 10 -week-old $G$. fasciculatum inoculum (roots, spores, mycelium, and soil) and grown in a constant environment chamber $\left(300 \mu \mathrm{E} \mathrm{cm} \mathrm{cm}^{-2} \mathrm{~s}^{-1}, 18 / 22^{\circ} \mathrm{C}, 16\right.$-h photoperiod, and $70 \%$ relative humidity). The plants were provided with a modified nutrient Long Ashton solution (Hewitt 1966) without phosphate but with $15 \mathrm{mM}$ nitrate to ensure nodulation-free conditions. Alternatively, we used an axenic in vitro mycorrhization system, which was developed in our laboratory in collaboration with G. Bécard (Vernoud 1999). Magenta boxes containing $60 \mathrm{ml}$ of sterile solid $\mathrm{M}$ medium (Bécard and Fortin 1988) with $0.2 \%$ (wt/vol) Phytagel (Sigma, St. Louis, MO, U.S.A.) were initially inoculated with the G. intraradices-carrot hairy root dual culture (see above) and grown at $25^{\circ} \mathrm{C}$ in the dark. After approximately 6 weeks, fungal hyphae had colonized most of the medium and the first newly formed spores were visible. The medium was then washed five times (90-min immersion per wash) with approximately $100 \mathrm{ml}$ of fresh M liquid medium lacking sucrose. Surface-sterilized, germinated seedlings of transgenic $M$. truncatula or $M$. varia were then planted in the Magenta box medium (up to 15 seedlings per box) so that the developing roots grew vertically through the highly infectious hyphal network. Plants could be grown for 2 to 3 weeks in a growth chamber under these conditions $\left(25^{\circ} \mathrm{C}, 16-\mathrm{h}\right.$ photoperiod, $\left.70 \mu \mathrm{E} \mathrm{m}^{-2} \mathrm{~s}^{-1}\right)$.

\section{In situ hybridization.}

For the preparation of the single-stranded RNA probes, the 430-bp internal MaeI-BstEII restriction fragment from the

\footnotetext{
$\leftarrow$

Fig. 3. Histochemical analysis of MtENOD11-gusA expression in transgenic $M$. truncatula A-D, during the arbuscular mycorrhizal symbiosis and $\mathbf{E}-\mathbf{N}$, in nonsymbiotic tissues. A, Whole root segment showing GUS activity in arbuscular mycorrhizal-colonized inner root cortical cells. External hyphae (arrowheads) and spores of Glomus intraradices are stained red with acid fuchsin. Bar $=250 \mu \mathrm{m} . \mathbf{B}, 80-\mu \mathrm{m}$ transverse root section of a colonized root. Bar $=150 \mu \mathrm{m}$. C, Semi-thin transverse section $(4 \mu \mathrm{m}$; counterstained with toluidine blue $)$ of a colonized root. Arrows indicate sections through internal hyphae and arrowheads indicate arbuscule-containing cells. Bar $=80 \mu \mathrm{m}$. D, Detail of arbuscule-containing cells after double staining with Magenta-glcUA for GUS activity (in red) and ink and vinegar for fungal structures (in dark-blue). Arrow points to an internal hypha. Bar $=60 \mu \mathrm{m}$. $\mathbf{E}$, Longitudinal thin section $(4 \mu \mathrm{m})$ of root tip viewed under dark-field optics. GUS activity (blue staining appears reddish in dark-field) is associated with cells of the root cap that surrounds the root meristem. Bar $=125 \mu \mathrm{m}$. F, Lateral root primordium within a whole root segment. GUS staining marks the first dividing pericycle cells next to the root vascular strands (star). Bar $=75 \mu \mathrm{m}$. G, Abaxial part of a fully expanded seedling cotyledon showing GUS activity associated with the whole vascular network. Bar $=600 \mu \mathrm{m}$. H, Portion of a recently opened leaf showing GUS activity associated predominantly with the minor vein network. Bar $=750 \mu \mathrm{m}$. I, Stomatal guard cells on the leaf stalk epidermis with strong GUS activity. Bar $=30 \mu \mathrm{m}$. J, Glandular trichome located on a young stalk and showing intense GUS activity. Note that GUS staining is absent for the two stomata visible on this image (see text). Bar $=50 \mu \mathrm{m}$. $\mathbf{K}$, GUS activity in the embryo suspensor (11 days after pollination), which remains attached to the embryonic root tip. Bar $=500 \mu \mathrm{m}$. L, GUS staining of whole maturing embryo 3 weeks after pollination. Staining is associated with the outer surface of cotyledons, correlating with the distribution of epidermal transfer cells in these organs (Weber et al. 1998). Bar $=750 \mu \mathrm{m}$. M, Whole endosperm (15 days after pollination) stained after removal of embryo. Bar $=750$ $\mu \mathrm{m}$. N, Detail of the GUS-positive outer cell layer of the endosperm exhibiting a characteristic cell morphology. $\operatorname{Bar}=50 \mu \mathrm{m}$.
} 
MtENOD11 gene was subcloned into pBlueScript $\mathrm{KS}^{+}$and $\mathrm{SK}^{+}$vectors (Stratagene, La Jolla, CA, U.S.A.). RNA synthesis with T7 DNA polymerase and partial hydrolysis of radiolabeled sense and antisense RNA was carried out as described in De Billy et al. (1991). In situ hybridizations on 7- $\mu$ m nodule sections with ${ }^{35} \mathrm{~S}$-labeled riboprobes were performed as described previously (De Billy et al. 1991), except for the addition of a 24-h prehybridization step with the standard hybridization buffer minus dextran sulfate.

\section{Histochemical localization \\ of reporter enzyme activities and fungal structures.}

Histochemical staining (blue) for $\beta$-glucuronidase (GUS) activity was performed on whole-root segments for up to $24 \mathrm{~h}$ with the substrate X-glcUA (5-bromo-4-chloro-3-indolyl glucuronide, cyclohexylammonium salt) (Biosynth, Staad, Switzerland) as described in Journet et al. (1994). Alternatively, the Magenta-glcUA substrate (Biosynth) was used to obtain red-colored GUS staining. Stem, leaf, and flower pieces were vacuum infiltrated and stained in the presence of $0.02 \%$ Triton $\mathrm{X}-100$. Intact nodules were prefixed with $0.5 \%$ paraformaldehyde prior to slicing into $80-\mu \mathrm{m}$ sections (Microcut H1200; Bio-Rad, Hercules, CA, U.S.A.). GUS staining times for sections were generally below $2 \mathrm{~h}$. When necessary, stained intact samples or slices were cleared briefly with sodium hypochlorite, as described in Pichon et al. (1992), or with $100 \%$ ethanol for chlorophyll-containing explants and observed with a Wild/Leitz stereomicroscope (Leica Microsystems, Wetzler, Germany) or a Zeiss Axiophot light microscope (Carl Zeiss, Le Pecq, France). For the localization of GUS activity at the cellular level, stained roots were postfixed for $1 \mathrm{~h}$ in $2.5 \%$ glutaraldehyde buffered in $0.1 \mathrm{M}$ potassium phosphate $(\mathrm{pH}$ 7.0), dehydrated in an alcohol series, and embedded in Technovit 7100 resin (Heraeus Kulzer, Wehrheim, Germany). Sections $(4 \mu \mathrm{m})$ were observed with bright- and dark-field microscopy after counterstaining using basic fuchsin $(0.5 \%$ in distilled water).

\section{Glomus mosseae}

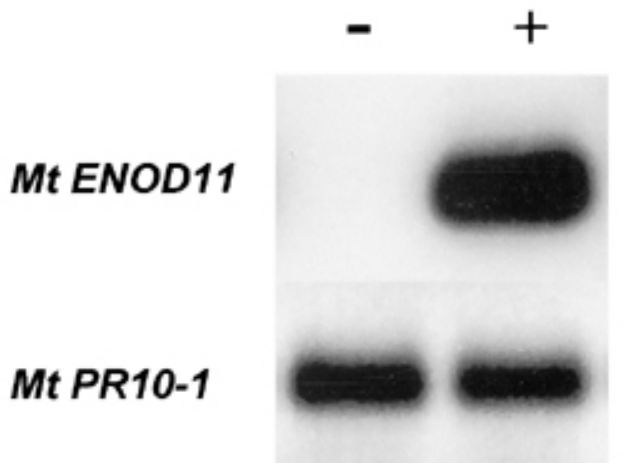

Fig. 4. Transcriptional activation of MtENOD11 in Medicago truncatula arbuscular mycorrhiza. Total RNA was extracted from entire root systems of M. truncatula plants 2 weeks postinoculation with Glomus mosseae and from noninoculated control plants. MtENOD11 transcript levels were evaluated by reverse transcription-polymerase chain reaction analysis (see text). Constitutive expression of the MtPR10-1 gene was used as an internal control for the quality and quantity of cDNA samples. Identical results were obtained in three independent experiments.
After digestion of mycorrhizal samples with $10 \% \mathrm{KOH}$ $\left(90^{\circ} \mathrm{C}, 10\right.$ to $\left.45 \mathrm{~min}\right)$, total fungal structures were stained with either $0.05 \%$ (wt/vol) Trypan blue, $0.5 \%$ (wt/vol) acid fuchsin (Bundrett et al. 1984), or ink and vinegar (Vierheilig et al. 1998). The double-staining procedure used for mychorrhizal roots to detect both GUS (Magenta-glcUA) and fungal structures (ink and vinegar) was developed by M. Chabaud. Fungal alkaline phosphatase activity was localized after staining with $\alpha$-napthyl phosphate (Tisserant et al. 1993). Parameters of mycorrhizal colonization (mycorrhizal frequency, $\mathrm{F} \%$; arbuscule abundance, $A \%$ ) were determined after staining according to Trouvelot et al. (1986).

\section{RT-PCR assay to detect MtENOD11 transcripts.}

Jemalong J5 seedlings were transferred to small, 100-ml multipots, which were inoculated with the fungal isolate $G$. mosseae (BEG 12) and watered with a modified nutrient Long Ashton solution without phosphate, as described above. Whole root systems of 7 to 16 plants per sample were harvested 2 and 3 weeks after transplantation and ground in liquid nitrogen. Total RNA was isolated by a standard phenolsodium dodecyl sulfate protocol and quantified using spectrophotometry and agarose gel electrophoresis. Prior to RT-PCR, genomic DNA was eliminated and the first cDNA strand was synthesized, as described in Pingret et al. (1998). cDNA aliquots $(2 \mu \mathrm{l})$, equivalent to $60 \mathrm{ng}$ of initial total RNA, were then used in PCR reactions. A 437-bp MtENOD11 cDNA fragment was amplified $\left(30\right.$ cycles at $94^{\circ} \mathrm{C}$ for $30 \mathrm{~s}, 60^{\circ} \mathrm{C}$ for $30 \mathrm{~s}$, and $72^{\circ} \mathrm{C}$ for $30 \mathrm{~s}$ ) at nucleotide positions 83 to 519 (relative to the ATG codon) of the genomic sequence (EMBL accession no. AJ297721) with forward primer 5'-CTCCATCCCACAATATGCCTCC-3' and reverse primer 5' ${ }^{\prime}$-ATGGATGCTAGGTGGAGGCT-3'. Parallel amplification of the gene MtPR10-1 expressed constitutively in roots (Gamas et al. 1998) (GenBank accession no. Y08726) was performed to control for equivalent cDNA levels in samples. MtPR10-1 cDNA was amplified during 22 cycles according to Pingret et al. (1998). PCR products were analyzed by Southern blotting and hybridization with a 430-bp internal MaeI-BstEII DNA

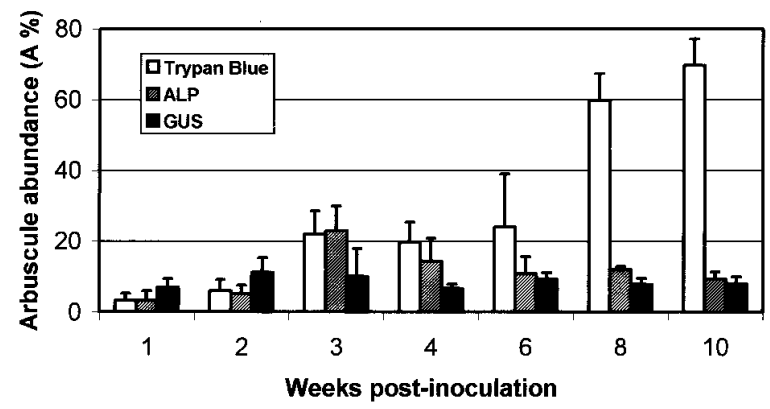

Fig. 5. Time-course experiment illustrating the relationship between the extent of root colonization, arbuscule functionality, and pMtENOD11gusA expression. Whole root systems of transgenic Medicago varia inoculated with Glomus fasciculatum were harvested at the indicated time points, and samples (30 randomly selected $1-\mathrm{cm}$ fragments per treatment) were stained for fungal structures (trypan blue), fungal alkaline phosphatase (ALP), or reporter GUS activity. Four plants per time point were used as replicates. Percentage values of arbuscule abundance as revealed by the various histochemical staining procedures were estimated according to Trouvelot et al. (1986). Small bars indicate standard deviations. 
fragment from MtENOD11 and the complete cDNA from MtPR10-1. Identical results were obtained whether plants were grown in the absence or presence of $15 \mathrm{mM}$ nitrate (to inhibit nodulation by possible contaminating rhizobia), confirming that the MtENOD11 signal was not the result of rhizobial contamination of the fungal inoculum.

\section{ACKNOWLEDGMENTS}

We are grateful to T. Bisseling (Wageningen, The Netherlands) for his initial gift of the PsENOD12 cDNA clone, and to G. Bécard (Université P. Sabatier, Toulouse, France) for providing us with an axenic Glomus intraradices-hairy root dual culture and his expert advice during the setting up of the axenic in vitro mycorrhization system. Our thanks also to M. Chabaud for providing us with the photograph illustrating the double staining (for GUS activity and fungal tissue) of the arbusculecontaining cells, M. Chabaud and Pascal Gamas for critical reading of the manuscript, and other colleagues for helpful comments. Financial support was provided by INRA (AIP Biologie du Développement 199597), the $E U$ in the framework of TMR network funding (ref. ERBFMRXCT980243), the Human Frontier Research Program (ref. RG327/98), and INRA-CNRS for the Medicago truncatula genome project (1998-2000). V. Vernoud received a Ph.D. grant from the French Ministère de l'Enseignement Supérieur et de la Recherche.

\section{LITERATURE CITED}

Albrecht, C., Geurts, R., Lapeyrie, F., and Bisseling, T. 1998. Endomycorrhizae and rhizobial Nod factors both require $S Y M 8$ to induce the expression of the early nodulin genes PsENOD5 and PsENOD12A. Plant J. 15:605-614.

Albrecht, C., Geurts, R. and Bisseling, T. 1999. Legume nodulation and mycorrhizae formation: Two extremes in host specificity meet. EMBO J. 18:281-288.

Alexander, T., Toth, R., Meier, R., and Weber, H. C. 1989. Dynamics of arbuscule development and degeneration in onion, bean and tomato with reference to vesicular-arbuscular mycorrhizae in grasses. Can. J. Bot. 67:2505-2513.

Allison, L. A., Kiss, G. B., Bauer, P., Poiret, M., Pierre, M., Savouré, A., Kondorosi, E., and Kondorosi, A. 1993. Identification of two alfalfa early nodulin genes with homology to members of the pea ENOD12 gene family. Plant Mol. Biol. 21:375-380.

Assmann, S. M. 1993. Signal transduction in guard cells. Annu. Rev. Cell Biol. 9:345-375.

Bauer, P., Ratet, P., Crespi, M. D., Schultze, M., and Kondorosi, A. 1996. Nod factors and cytokinins induce similar cortical cell division, amyloplast deposition and MsEnod12A expression patterns in alfalfa roots. Plant J. 10:91-105.

Bécard, G., and Fortin, J. A. 1988. Early events of vesicular-arbuscular mycorrhiza formation on Ri T-DNA transformed roots. New Phytol. 108:211-218.

Bécard, G., and Piché, Y. 1992. Establishment of vesicular-arbuscular mycorrhiza in root organ culture: Review and proposed methodology. Pages 89-108 in: Methods in Microbiology, Vol. 24. J. R. Norris, D. J. Read, and A. K. Varma, eds. Academic Press, London.

Bhuvaneswari, T. V., Bhagwat, A. A., and Bauer, W. D. 1981. Transient susceptibility of root cells in four common legumes to nodulation by Rhizobia. Plant Physiol. 68:1144-1149.

Bonfante, P. 2001. At the interface between mycorrhizal fungi and plants: The structural organization of cell wall, plasma membrane and cytoskeleton. Pages 45-61 in: The Mycota IX, Fungal Associations. B. Hock, ed. Springer-Verlag, Berlin.

Bundrett, M. C., Piché, Y., and Peterson, R. L. 1984. A new method for observing the morphology of vesicular-arbuscular mycorrhizae. Can. J. Bot. 62:2128-2134.

Caetano-Anollés, G., and Gresshoff, P. M. 1991. Alfalfa controls nodulation during the onset of Rhizobium-induced cortical cell division. Plant Physiol. 95:366-373.

Camporota, P. 1989. Maladies des plantes dues à Rhizoctonia solani (Khün): Stratégie et techniques d'études. Agronomie 9:327-334.

Carpita, N. C., and Gibeaut, D. M. 1993. Structural models of primary cell walls in flowering plants: Consistency of molecular structure with the physical properties of the walls during growth. Plant J. 3:1-30.

Chabaud, M., Larsonneau, C., Marmouget, C., and Huguet, T. 1996. Transformation of barrel medic (Medicago truncatula Gaertn) by Agrobacterium tumefaciens and regeneration via somatic embryogenesis of transgenic plants with the MtENOD12 nodulin promoter fused to the gus reporter gene. Plant Cell Rep. 15:305-310.

Charlton, W. A. 1996. Lateral root initiation. Pages 149-173 in: Plant Roots: The Hidden Half, 2nd ed. Y. Waisel, A. Eskel, and U. Kafkafi, eds. Marcel Dekker, New York.

Coté, G. G. 1995. Signal transduction in leaf movement. Plant Physiol. 109:729-734.

Csanadi, G., Szecsi, J., Kalo, P., Kiss, P., Endre, G., Kondorosi, A., Kondorosi, E., and Kiss, G.B. 1994. ENOD12, an early nodulin gene, is not required for nodule formation and efficient nitrogen fixation in alfalfa. Plant Cell 6:201-213.

De Billy, F., Barker, D. G., Gallusci, P., and Truchet, G. 1991. Leghaemoglobin gene transcription is triggered in a single cell layer of the indeterminate nitrogen-fixing root nodule of alfalfa. Plant $\mathrm{J}$. $1: 27-35$.

Esau, K. 1977. Anatomy of Seed Plants, 2nd ed. Wiley \& Sons, New York.

Frühling, M., Roussel, H., Gianinazzi-Pearson, V., Puhler, A., and Perlick, A. M. 1997. The Vicia faba leghemoglobin gene VfLb29 is induced in root nodules and in roots colonized by the arbuscular mycorrhizal fungus Glomus fasciculatum. Mol. Plant-Microbe Interact. 10:124-131.

Gallagher, S. R. 1992. GUS protocols: Using the GUS gene as a reporter of gene expression. S. R. Gallagher, ed. Academic Press, London.

Gallusci, P., Dedieu, A., Journet, E.-P., Huguet, T., and Barker, D. G. 1991. Synchronous expression of leghaemoglobin genes in Medicago truncatula during nitrogen-fixing root nodule development and response to exogenously supplied nitrate. Plant Mol. Biol. 17:335-349.

Gamas, P., Niebel, F. D. C., Lescure, N., and Cullimore, J. V. 1996. Use of a subtractive hybridization approach to identify new Medicago truncatula genes induced during root nodule development. Mol. Plant-Microbe Interact. 9:233-242.

Gamas, P., De Billy, F., and Truchet, G. 1998. Symbiosis-specific expression of two Medicago truncatula nodulin genes, MtN1 and MtN13, encoding products homologous to plant defense proteins. Mol. Plant-Microbe Interact. 11:393-403.

Gianinazzi-Pearson, V. 1996. Plant cell responses to arbuscular mycorrhizal fungi: Getting to the roots of the symbiosis. Plant Cell 8:1871-1883.

Gianinazzi-Pearson, V. 1997. Have common plant systems co-evolved in fungal and bacterial root symbioses? Pages 321-324 in: Biological Fixation of Nitrogen for Ecology and Sustainable Agriculture: NATO ASI Series, Vol G39. A. Legocki, H. Bothe, and A. Puhler, eds. Springer-Verlag, Berlin.

Hadri, A. E., Spaink, H. P., Bisseling, T., and Brewin, N. J. 1998. Diversity of root nodulation and rhizobial infection process. Pages 347-360 in: The Rhizobiaceae-Molecular biology of model plant-associated bacteria. H. P. Spaink, A. Kondorosi, and P. J. J. Hooykaas, eds. Kluwer Academic Publishers, Dordrecht, The Netherlands.

Harrison, M. J. 1997. The arbuscular mycorrhizal symbiosis: An underground association. Trends Plant Sci. 2:54-56.

Harrison, M. J. 1999. Molecular and cellular aspects of the arbuscular mycorrhizal symbiosis. Annu. Rev. Plant Physiol. Plant Mol. Biol. 50:361-389.

Hawes, M. C., Brigham, L. A., Wen, F., Woo, H., and Zhu, Y. 1998. Function of root border cells in plant health: Pioneers in the rhizosphere. Annu. Rev. Phytopathol. 36:311-327.

Hewitt, E. J. 1966. Sand and water culture methods used in the study of plant nutrition. Pages 430-434 in: Technical Communication, 22nd ed. Commonwealth Agricultural Bureau, London.

Hong, J. C., Nagao, R. T., and Key, J. L. 1990. Characterization of a proline-rich cell wall protein gene family of soybean. A comparative analysis. J. Biol. Chem. 265:2470-2475.

Journet, E.-P., Pichon, M., Dedieu, A., De Billy, F., Truchet, G., and Barker, D. G. 1994. Rhizobium meliloti Nod factors elicit cell-specific transcription of the ENOD12 gene in transgenic alfalfa. Plant J. 6:241249.

Kieliszewski, M. J., and Lamport, D. T. 1994. Extensin: Repetitive motifs, functional sites, post-translational codes, and phylogeny. Plant J. 
5:157-72.

LaRue, T. A., and Weeden, N. F. 1994. The symbiosis genes of the host. Pages 147-151 in: Proceedings of the 1st European Nitrogen Fixation Conference. G. B. Kiss and G. Endre, eds. Officina Press, Szeged, Hungary.

Löbler, M., and Hirsch, A. M. 1993. A gene that encodes a proline-rich nodulin with limited homology to PsENOD12 is expressed in the invasion zone of Rhizobium meliloti-induced alfalfa root nodules. Plant Physiol. 103:21-30.

Lopes, M. A., and Larkins, B. A. 1993. Endosperm origin, development, and function. Plant Cell 5:1383-1399.

Mylona, P., Pawlowski, K., and Bisseling, T. 1995. Symbiotic nitrogen fixation. Plant Cell 7:869-885.

Pawlowski, K. 1997. Nodule-specific gene expression. Physiol. Plantarum 99:617-631

Penmetsa, R. V., and Cook, D. R. 1997. A legume ethylene-insensitive mutant hyperinfected by its rhizobial symbiont. Science 275:527-530.

Pichon, M., Journet, E.-P., Dedieu, A., De Billy, F., Truchet, G., and Barker, D. G. 1992. Rhizobium meliloti elicits transient expression of the early nodulin gene ENOD12 in the differentiating root epidermis of transgenic alfalfa. Plant Cell 4:1199-1211.

Pichon, M., Journet, E.-P., De Billy, F., Dedieu, A., Huguet, T., Truchet, G., and Barker, D. G. 1994. ENOD12 gene expression as a molecular marker for comparing Rhizobium-dependent and -independent nodulation in alfalfa. Mol. Plant-Microbe Interact. 7:740-747.

Pingret, J. L., Journet, E.-P., and Barker, D. G. 1998. Rhizobium nod factor signaling. Evidence for a $G$ protein-mediated transduction mechanism. Plant Cell 10:659-672.

Rougier, M. 1981. Secretory activity of the root cap. Pages 542-574 in: Encyclopedia of Plant Physiology, Vol. 13B. W. Tanner and F. A. Loewus, eds. Springer-Verlag, Berlin.

Scheres, B., Van de Wiel, C., Zalensky, A., Horvath, B., Spaink, H., Van Eck, H., Zwartkruis, F., Wolters, A.-M., Gloudemans, T., Van Kammen, A., and Bisseling, T. 1990. The ENOD12 gene product is involved in the infection process during the pea-Rhizobium interaction. Cell 60:281-294.

Schultze, M., and Kondorosi, A. 1998. Regulation of symbiotic root nodule development. Annu. Rev. Genet. 32:33-57.

Sherrier, D. J., and VandenBosch, K. 1994. Localization of repetitive proline-rich proteins in the extracellular matrix of pea root nodules. Protoplasma 183:148-161.

Showalter, A. M. 1993. Structure and function of plant cell wall proteins. Plant Cell 5:9-23.

Smith, S. E., and Gianinazzi-Pearson, V. 1988. Physiological interactions between symbionts in vesicular-arbuscular mycorrhizal plants. Annu. Rev. Plant Physiol. Plant Mol. Biol. 39:221-244.

Smith, S. E., and Smith, F. A. 1990. Structure and function of the interfaces in biotrophic symbioses as they relate to nutrient transport. New Phytol. 114:1-38.

Smith, S. E., and Read D. J. 1997. Mycorrhizal Symbiosis, 2nd ed. Academic Press, London.
Tisserant, B., Gianinazzi-Pearson, V., Gianinazzi, S., and Gollotte, A. 1993. In planta histochemical staining of fungal alkaline phosphatase activity for analysis of efficient arbuscular mycorrhizal infections. Mycol. Res. 97:245-250.

Tisserant, B., Gianinazzi, S., and Gianinazzi-Pearson, V. 1996. Relationships between lateral root order, arbuscular mycorrhiza development, and the physiological state of the symbiotic fungus in Platanus acerifolia. Can. J. Bot. 74:1947-1955.

Trouvelot, A., Kough, J. L., and Gianinazzi-Pearson, V. 1986. Mesure du taux de mycorhization VA d'un système radiculaire. Recherche de méthodes d'estimation ayant une signification fonctionnelle. Pages 217-221 in: Physiological and Genetic Aspects of Mycorrhizae. V. Gianinazzi-Pearson and S. Gianinazzi, eds. INRA Press, Paris.

Van Rhijn, P., Fang, Y., Galili, S., Shaul, O., Atzmon, N., Wininger, S., Eshed, Y., Lum, M., Li, Y., To, V., Fujishige, N., Kapulnik, Y., and Hirsch, A. M. 1997. Expression of early nodulin genes in alfalfa mycorrhizae indicates that signal transduction pathways used in forming arbuscular mycorrhizae and Rhizobium-induced nodules may be conserved. Proc. Natl. Acad. Sci. USA 94:5467-5472.

Vasse, J., De Billy, F., and Truchet, G. 1990. Correlation between ultrastructural differentiation of bacteroids and nitrogen fixation in alfalfa nodules. J. Bacteriol. 172:4295-4306.

Vernoud, V. 1999. Le gene MtENOD20: Un marqueur moléculaire précoce de l'organogenèse nodulaire lors de l'interaction symbiotique Sinorhizobium meliloti/Medicago. PhD thesis. Université P. Sabatier, Toulouse, France.

Vernoud, V., Journet, E.-P., and Barker, D. G. 1999. MtENOD20, a Nod factor-inducible molecular marker for root cortical cell activation. Mol. Plant-Microbe Interact. 12:604-614.

Vierheilig, H., Coughlan, A. P., Wyss, U., and Piché, Y. 1998. Ink and vinegar, a simple staining technique for arbuscular-mycorrhizal fungi. Appl. Environ. Microbiol. 64:5004-5007.

Vijn, I., Yang, W. C., Pallisgard, N., Jensen, E. O., Van Kammen, A., and Bisseling. T. 1995. VsENOD5, VsENOD12 and VsENOD40 expression during Rhizobium-induced nodule formation on Vicia sativa roots. Plant Mol. Biol. 28:1111-1119.

Von Heijne, G. 1983. Patterns of amino-acids near signal sequence cleavage sites. Eur. J. Biochem. 133:17-21.

Wagner, G. J. 1991. Secreting glandular trichomes: More than just hairs. Plant Physiol. 96:675-679.

Weber, H., Heim, U., Golombek, S., Borisjuk, L., and Wobus, U. 1998 Assimilate uptake and the regulation of seed development. Seed Sci. Res. 8:331-345.

Wilson, R. C., Long, F., Maruoka, E. M., and Cooper, J. B. 1994. A new proline-rich early nodulin from Medicago truncatula is highly expressed in nodule meristematic cells. Plant Cell 6:1265-1275.

Ye, Z. H., Song, Y. R., Marcus, A., and Varner, J. E. 1991. Comparative Localization of three classes of cell wall proteins. Plant $\mathrm{J}$. $1: 175-183$.

Yeung, E. C., and Meinke, D. W. 1993. Embryogenesis in angiosperms: Development of the suspensor. Plant Cell 5:1371-1381. 